\title{
The Mirrors for Princes and Historical Codes of the Modern Leadership in the Middle East.
}

\author{
Dr. Mustafa Altunok \\ Abant İzzet Baysal University
}

\begin{abstract}
The Mirrors for Princes are administrative texts of ancient history. These texts, referred to by different names, are considered to be important because they have a function of projection, for rulers of the period. And their importance is not limited by this, because of its features. Since criticism and suggestions for the next ruler also shows the people's expectations, it is a reflection of the social and political characteristics of the period as well as texts. However, the Mirrors for Princes is not merely an object or the text to understand history or a period of time because these texts are elements of historical and social memory. From the text, written in the changing conditions and at different times, it can be understood that there were changing political and societal realities as well as unchanging elements. In this respect, the Mirrors for Princes can be considered not only an illumination of the past, staying in the dusty shelves of history, but also a relevant reflection that reaches to now. The main purpose of this study is to find out the secrets of leadership from this reflection. The main argument of this study is that this region has a historical code of the current leadership, which can be interpreted by the Mirrors for Princes. The backbone of the work depends on the interpretation and analysis of the Mirrors for Princes. This text was written in different times for different rulers; it raised powerful leaders from the Ottoman, Seljuk, Mongol, and Iranian societies. This research seeks to find out a different leader perception typology from commonalities despite social differences to different states and periodic variations. Considering that the Mirrors for Princes is an extensive literature, this study should be evaluated as a motivational tool for comprehensive successors.
\end{abstract}

Keywords: Mirror for Princes, Mirror for Princes and Sultans, Mirror for The Muslim Princes, Circle of Justice, Leadership

\section{Introduction}

As a period when the computer and the internet network surrounds the whole world, there are many possibilities for academicians and specialists (practitioners or theoreticians) who work in fields such as political science, sociology, public administration and social sciences to easily and quickly reach a lot of data that can be used to analyze or understand a society or its administrational and political system. These possibilities, of course, are often narrowed or distorted by some censorship, constraints or manipulations. However, it is clear that the availability of detailed information, especially through data banks or search engines, is too large to compare with previous periods. In this sense, it can be considered that the societies are getting close to each other in terms of life patterns, consumption habits, expectation of welfare and freedom. However, in this new small globe, whose distances are shortened, communication and transportation facilities are developed, the flow of life is accelerated, and thus the differences are reduced, it is expected that people living in different societies should not have any difficulties in understanding leaders and their rhetoric and reactions. However, it is seen that theoreticians or practitioners, especially from within the formation which can be called Western-style political understanding, often have difficulty in understanding the Orient specific-especially the Middle East-. In this sense, one of the most basic and functional means to trace the history of the codes of political and administrative reality appears as the mirrors for princes.

Although societies are becoming increasingly differentiated and increasingly similar to each other in their development, they eventually have codes that carry them from the past to today. Even though they are in the same country and within the same political system, cities are differentiated according to their spatial and architectural qualities; it is mentioned that cities have souls and they are distinguished from each other while living together. Societies on a higher scale are also 
different due to Rams and Memes which they brought from history. Therefore, it is possible to say that in the sense of social and managerial reality, today's general view of the past or today's given data will not be enough alone, or at least past accumulation and experience will facilitate understanding. In this sense, one of the most basic and functional means to trace the history of the codes of political and administrative reality appears as the mirrors for princes.

\section{Mirrors of Princes and Eastern Texts}

The term "mirror for prince", when considered in general, emerges as a conceptualisation peculiar to the West. The mirrors for princes can be regarded as basic texts with mirror-like qualities for any historical period review. It is not possible to encounter western mirrors for princes in east in the same sense. The works which are in the Turkish - Persian and Arab tradition dominant in the Middle East and which resemble the mirrors for princes in the West are generally texts such as politics, advice, pleadings, and travel books. Anthony Black, as a worker on Eastern and Western political thought, describes the Islamic political thought in the first five centuries in his work The West ... and explains this in three ways. These are: Nasihat al Muluk, which he regards as the recommendation texts to kings, fiqh which he describes as religious law and a New Platonist understanding of philosophy. (Black, 2008:8)

In the same work, Black explains that the Islamic experts often compare the works of Nasihat-ul Muluk (Nasihat al Muluk) with the western mirrors for princes, whereas they are different from those of the monarchical state in Europe and The nasihatulmuluk-like qualitative works written as a recommendation to kings were written in the Muslim world much earlier and more variously than the first European examples and one of the most important examples is the Politics of NizamülMülk. Besides, one of the most important channels in political Islam is the Iranian effect. (Black, 2008: 101-102 ; Black,2011)

Pal Fodor is encountered as a remarkable name for the western mirrors for princes and eastern style political texts (The Politics of the Orient). Fodor explains why he uses the expression mirrors for princes instead of the words like politics, pleadings, and advice in his studies of the monarchs of the East. According to this, there are a lot of factors in Fodor's choosing the expression mirrors for princes of Europe or of the kings in the same way. The most important of these is the fact that the expression mirror of the prince is more comprehensive than the other determinations, and on the other hand it presents the opportunity to recognize the mirrors of the traditionally rich princes of the near east'. In addition, according to the authors, the texts of the Ottoman monarch's mirrors are the continuation and complement of the Islamic monarch's mirrors. (Fodor, 1999: 281-282 )

The mirrors for princes or another opinion on the discussion of politics belongs to $\mathrm{H}$ Bahadır Türk as the author of the book titled Shepherd and King which is one of the most comprehensive analysis written in Turkish. After entering the discussion on this subject, he states that his choice of politics corresponded to the mirrors princes in the Western literature and even their equivalents. (Türk,2012: 23-35). Although the above-mentioned authors have differences regarding the processing of these matters, they at least agree that the subject is at the forefront and scope of the subject, and that the Eastern texts of politics or advice are as important and interesting as the mirrors for princes. From this point of view, it will be appropriate to admit that the Middle Eastern texts of this frame, in particular, meet at least the qualification of mirrors for princes.

\section{General Framework of Mirrors for Princes (Importance, Origin and Scope)}

The mirrors for princes contain important clues about the time of the state they tell, the state administration, their functions, and the experience and political accumulation of administrators. These texts are not only an indication of the legitimacy and limits of power, but also provide access to the views of the political elite who think in this respect (Fodor,1999: 281). It is also possible to see how the understanding of worldly and prestigious power is fostered through these texts.

The Islamic-based Middle East oriented mirrors for princes carry a number of difficulties as well as being richly descriptive and guiding rich texts for researchers of this field. It is possible to draw a brief outline of what these difficulties are, by taking advantage of the findings of Ahmet Uğur in the form of "major problems of politics". (Uğur,1992: 13)

Firstly, one of the main difficulties of working in this field is the width of the field itself. Particularly in the 11th and 12th centuries, it appears that a large complex has emerged in this area. Moreover, the texts are written in Arabic, Turkish, Farsi and their combination of different languages such as the Ottoman language, and are the works close to the manuscript. This makes it difficult for readers to access and review works. 
Secondly, it is not easy to distinguish these texts which have different names such as justice letters, politics, pleadings, advice letters, and letters of Turkish-Islamic rules and regulations. It is hard to say that the authors of the works in this respect are also consensus on what they analyze and examine later.

Another problem similar to the above is that the same work is recorded in different names in libraries. This causes duplicate works to appear, preventing them from determining how many works they actually have, and thus creating a timeconsuming process. Another difficulty in this regard is that not all of the texts considered as the same as the mirrors for princes are directly related to this topic. It is seen that the vast majority of those which are involved are not receiving systematic remuneration or are randomly packed into a few pages.

Another important challenge is related to the identification information, such as the author and the names of the works. Many works prepared in this framework do not have clear information about the names of the authors or the history of the writings, but some are referred to in different dialects with different names and dates. Moreover, it is seen that many works have chosen a general name such as Siyasetname, Pendname or Nasihatül Mülük, which can cause confusion about the author and source of the book.

Another point that makes it difficult to study the mirrors for princes is that spiritual and earthly things are taken together, as Fodor also mentions it. (Fodor,1999: 281) More precisely, the root of a secular sovereignty can be fed on a religious or even sectarian basis, which reveals the fact that the view is influenced by sectarian and socio-cultural differences, even though the origin is the same religion. Of course, it is not easy to catch these social differences or nuances.

Mirrors for princes, with the subjects such as rulers and administration, can be regarded as basic texts for mirroring the state, society and the domination of the kingdom for any historical period examination. When assessed in this direction, it is necessary to consider that the formation of the social and political formation is an important function of the mirrors for princes. The mirrors for princes are usually written for three sections. These are generic ones written for rulers, viziers and senior executives, as well as for other literate sections of the society (Uğur,1992:7).

The roots of the mirrors for princes are quite early in the East. The general view in this regard links the beginning of politicsstyle texts with the post-Islamic period, especially with the Umayyad period. It is possible to explain this with the accumulation of the developed and comprehensive forms of such texts at a certain period. Fodor refers to the period of the fall of the Umayyads as the starting point for the first Islamic-based examples of politics and emphasizes that the internal political processes of the Arab-Islamic empire and the cultural endeavors to them are determinative in the formation of this tradition (Fodor, 1999: 282)

It is possible to say that Black does the same detection. However, it is often referred to Plato and Aristotle as early examples in the Western way, which extends to the 4th century. (Uğur,1992:3). In this sense, it is possible that the beginning of this style can be taken back further in the Middle East. Especially, some tablets in studies on Mesopotamian and Anatolian civilizations show that there are boundaries for rulers or administrators who will come after themselves thousands of years before, it is possible to count them as ancestors or first examples of politics, justice or laws.

As an example of the first politics in Turkish political life, Yusuf Has Hacip's Kutadgu Bilig is the starting point of his work. So this information is generally true, and even in the official education sites of the state, it is processed in the same frame. (www.eba.gov.tr) As it is known, this work was written in Karahanlilar period, the first Muslim Turkish state. In making this determination, it is necessary to admit that, of course, the value of the work as well as political religious motives is a specific determinant of its scope. However, the Orkhon Inscriptions, which were written long before this work, actually contain many political consultations and draw a framework on what should and should not be done for the state's presidency. The fact that one of these books belongs to the Vizier Tonyukuk can also be considered to strengthen this argument. Therefore, it would not be so wrong to accept the Orkhon Inscriptions written between 716 and 735 during the Göktürk period as the first Turkish mirror for prince as a sample of the text or at least as a substitute. (Taşağıl:2003)

As can be seen from the above frame, the extent of the scope of this deep history of the origins of the mirrors for princes originating in the Middle East is quite extensive. However, aside from starting from the primitive examples, it is impossible and even insignificant to try to fit into the work of even the entire text of the same mirror for prince in classic Islamic thought. In the last period of the Ottoman period, as a name that has been examined by the Bursalı Mehmet Tahir, a study of these works reveals the number of political Islamic works that can be reached in this way as 172 , which also shows how wide the scope is. (Uğur,1992:13-14) In addition, there are some difficulties in working on these works that have a mirror for prince 
as explained above. However, there is also the advantage of working in these texts that if the basic texts can be chosen, they should be of a quality that allows them to find the main points for the majority, if not all, due to similarities in approach, method and content. Therefore, a study has been carried out on the basis of the principal mirrors for princes in the Turkish Iranian and Islamic tradition, which is accepted as the basis in this study.

\section{Main Characteristics of the Mirrors for Princes}

The Mirrors for Princes are very important administrative texts. First, they provide considerable information about the political and administrative climate of the period. Such studies generally belong to two separate periods. A part of these texts-comparatively limited-were written in the most powerful period of the state. The second and more intense times of writing, were crisis periods. As a result, the writers aim to reflect and show the mistakes of the rulers of the time in which the old powerful state was in ashes.

In light of the above given information, it is possible to summarize the main features of ruler mirrors as follows:

Justices, politics, Islamic guild rules and regulations, pleadings, advices are the main kinds of mirrors for princes.

They carry mirror quality for the state and the ruler.

They include not only information about management and managers but also about the economic and social characteristics of the period.

They are mostly fed on a religious and sectarian basis and are framed as a moral attitude. In this respect, they are characteristic of moral texts.

It is observed that the mirrors for princes use a strong narrative language, which often uses authors' words, and that the reflections of the communal nature of the situation are in the foreground.

The issues they focus on may vary depending on the characteristics of the period they are written and the welfare of the society at this time, depending on the qualifications of the rulers.

The vast majority of those written during periods of crisis or malfeasance were written to lift the state again and to resume the limits of the religious and cultural legitimacy of the rulers. In this respect, they are reform documents.

In times of strong rulers who have a high level of prosperity and social satisfaction, it is often seen that the praise part is heavier and is prepared with a content about the continuity of the present situation.

Whereas the vast majority focuses on function, some of them, though limited, take structure, that is system, in the center.

The mirrors for princes were mostly built on a balance based on contrast.

These texts are generally not binding, they are works based on advice.

\section{Basic Characteristics of Mirrors for Princes: Religion, Balance and Justice}

\section{Religion as a Basic Element}

Looking at post-Islamic Middle Eastern texts of mirrors of prınces, these texts seem to contain three key elements. These are Religion, Balance and Justice. Religion is, of course, Islamic religion, and a state and leadership understanding must be adopted according to its needs. This point is a dimension that is not sufficiently emphasized when the issue of secularism, which is often skipped in comparison with Western state understanding, is on the agenda.

Almost all of the Post-Islamic Period Middle Eastern mirrors for princes, despite some sectarian and ethno cultural sociological differences, take into the center an understanding of religion based justice systems such as the Holy Book, Hadith, figh and Sunnah. In this sense, the ideal state conforms to this. The ideal leader is a good religious person and a Muslim. It is possible to give examples of this from almost every mirror for prince. The characteristics that the Ahl-i Sunnah Speakers call in their rulers are being Muslim, having reached the age of free-wise intelligence, being a man, having justice and knowledge, being devout and having virtue. (See Mehmet Evkuran, 2003, p.222; by Bahadır Türk page 100.) It should not be too surprising to see the reflection of the stated conception in this context in today's states or in their leaders. 


\section{Contrast or Balance?}

When one looks at the mirrors for princes as a whole, one of the most remarkable features is that they are based on contrasts. In fact, one of the most important characteristics of the general life practice of the Orient is the dilemmas. This situation manifests itself in the form of triplets in Western thought and life style. When you look at dilemmas, the first thing that attracts attention is a rationale based on contrast. This is again as it is in the example of the east, hidden in the TaiChi symbol Yin and Yang. As they are known, these are the contrasts of each other. However, in this contradiction there is a thought of "every side also contains the opposite." In this case it appears that three dimensions have come forward. The first is that there are two opposite truths, like good-bad, beautiful-ugly, right wrong. In the second dimension these two opposing elements are very close to each other and sometimes even inside and the third dimension is that the contrasts gain meaning together, and even life balance through these contrasts.

When we look at the rulers' mirror, a Tai Chi situation is encountered. Therefore, these texts are often interpreted as a contrasting expression. However, this situation brings with it a balance rather than a contrast. There are basic preferences or phenomena, one of which is positive and the other is negative, which are often given in a form that would accommodate a religious reference. But as long as these two are together, it is meaningful because the positive is fed by the weakness of the negative, or by the harm of the other and vice versa. When we look at the mirrors for princes, it is seen that this state is preferred not to give an emphasis of contradiction under its origin but to determine and adopt the ideal, and that the meaning imposed on the state of equilibrium is used in a way to overcome its contrasts. This is a matter of being measured in a sense. For example, the presence of hell is one of the most important instruments of providing the work to go to heaven. But at the same time, it is ideal to configure without escaping and exaggeration. When the texts are examined at large, it is seen that the necessary qualities and the features that should not be on a ruler are given together, or in the advice letters, it is seen that the same level of necessity is given to what should and should not be done. A common advice in this regard is on avoiding extravagance and understatement, and balance is the key element of such studies. Because the balance appears as a constitutive principle for the actions of the ruler, the ruler. (Türk,2012: 39)

Traces of the balance can be found at every point from the daily hustle of social life to the nuances of managerial life. With a few examples, it would be instructive to establish this balance issue. Equilibrium in religion, justice, military, administration, generosity, and even in sexuality is important. The question of equilibrium is so important in this social reality that Fodor explains the reasons for writing these texts outwardly through the exchange of balances among the great powers or by the alterations of the balances. (Fodor,1999: 281)

According to Tusi, justice is a balance. Instead of modesty and multiplicity, average makes it right. İbni Tevmiye says, "If the senior managers are mild-mannered, the assistants should be hard, and when they are not, the assistants must be soft-tempered". (Türk,2012: 123.) Maverdi counts the equilibrium elements such as a determined but not rigid, soft but not feeble, generous but not wasted person among the qualities of the person who will pass to the ummah with reference to Caliph Umar. (Maverdi,2013:105)

Es-Sealibî says "The ideal ruler, who acts with the principle of metering, should approach his bureaucrats with an ideal balance and know where to reward and punish them." Es- Sealibi points to the bond between the idea of the measure and justice. Because Justice is a state of balance (Türk,2012: 82) According to Sadi Shirazi, a just ruler resembles a solid wall. If it loses its equality of justice and leans on one side, it is necessary to know it will collapse. (Şirazi,2016: 102)

The balance of the army is emphasized in Koçi Bey Risales. According to Koçi Bey, the capillary army and the tarmar army must balance each other. When the tarmar system was broken and balanced, the capillary army took power and the economic power of the country. (Fodor,1999: 295-296) Al-fahri also refers to Ibnu Tiktaka Hüsrev Perviz's advice to his son. Accordingly, it is also dangerous to act too generously and to be stingy to soldiers. That's why you need to give a decent salary (tip) to the soldier.

According to Farabi's state understanding, when the balance that exists in nature is deteriorated in society life, social resolution becomes inevitable. (Hopaç,2016:371) Again, according to Farabi, the "leader" is to be characterized and to be measured in sexual desire as ethical characteristics when counting the qualities of the "leader" . (Islamic thinkers page 25) According to Tusi, a ruler should manage the situation of the community in balance with grace and hardness. (Tusi,2016: 188-189) In the Kabusname, another work in the same form as a mirror for prince, it is stated that very much 
or little of the sexuality is also harmful, and that a medium level of everything is nice, so that even the extreme heat and cold should be avoided and warm times should be chosen for sexuality. (Keykavus:288)

As it is known, in the case of mirrors for princes, it is seen that the author frequently resorted to the use of metaphors and words of condolence. The determination and the influence of these texts also come from this great significance. Even in the use of metaphors, one of the most common methods is balance. Some of the most frequently used metaphors are organismic metaphors, including body parts such as the heart and the head. According to Akhisari, Veysi and Koçi Bey, the ruler is the heart of the body and according to the writer of Kitab-I Müstetab, the ruler is the soul of the body. According to Veysî, if the heart is not regular and loses its balance, the disorder will definitely occur in the case of the body. (Fodor,1999: 299-300)

\section{Entering the Justice Charter or Managing with the Verge of Justice}

The concept of justice is one of the main areas of debate in every period of Islamic societies. When the mirrors for princes are examined, this concept appears to be in the center (Fodor,1999: 283) The fact that this concept is centralized and so many discussed can be interpreted in two ways. First, justice is of utmost importance in terms of religion and societies, and it is very important for these social structures. Secondly, if this issue occupies an important agenda, it is probable that serious problems related to the issue are also occurring. Today, Middle Eastern societies are often at the center of justicebased debates. It is not a coincidence that problems often come to the fore in different dimensions of adulthood in narrower fields such as social justice, income justice and justice in representation, in particular the problem of justice in general.

Justice is of the utmost importance because it is an ordained command before everything else. In the Qur'an, it is said "Allah surely orders justice, goodness and looking after relatives, and forbids shamelessness, mischief and extravagance. As mentioned above, there is a search for a religious notion and an equilibrium situation at the root of justice. Therefore, these three concepts are in fact close to each other and complement each other. And these are the bases upon which the earth is built. Thus, according to Yusuf Has Hajib, the law restricting adherence is a pole for this sky; if the law breaks down, the sky cannot stand in place. (Kutadgu Bilig 3463. couplet) Justice is a siege for society. Justice in this sense is metaphorically like a circle. The circle should be considered in two forms; the first being socially enveloping and the second one being restrictive in terms of the ruler.

It may seem controversial how limited the kingdom of God as the shadow of the earth will be, but in the end it is a reality. Therefore, a ruler who wants to rule with justice must take all the classes of his people into this circle, and himself must rule with divine justice. Justice and equity for the sultan are seen as a source of righteous behavior ... cruelty and injustice are regarded as the reason for the disintegration of the subject. (Pal Fodor, quoted from Salimzjanova and Karckson, $p$. 300)

When we look within the boundaries of our topic, a few dimensions of justice come to the forefront. First, as mentioned above, there are mirrors for princes directly so-called justice. This topic will not be entered specifically here. Secondly, justice as opposed to cruelty; and just to cruel; is the instrument of balance and order. Thus, it deserves to be one of the most basic concepts even in this respect. As Inalcik emphasizes, the bond between absolute authority and justice, which has been in the Middle East for a long time, has become a fundamental principle. (Inalcık,1965:49) Thirdly, when justice, which was just described as a circle, turns out to be a verge from inside the circle, a very special concept (or even an approach), called the verge of Justice, and which has many economic social and administrative dimensions, is emerging.

Justice is so important that Nizamül Mülk, known as a religious vizier, in his famous work titled Politics, says "Empire will eventually stand with unbelief, but never with unfair". (Nizam'ül-Mülk, 1999) According to Ibn al Mukaffa, the best of the rulers is only able to secure his government with justice among his people. In his duty, in his word and in his action, a ruler is the man who must be the most adherent man. (Mukaffa,2016:131,59) According to Shayzari, justice is one of the four things that cannot be considered apart from the ruler. In addition, justice that provides obedience is regarded as one of the superior qualities for a ruler (Şeyzeri, 2013: 95). Yusuf Has Hacib states that justice should be pursued in this matter, and that even if necessary, it may be migrated elsewhere. Where a man finds justice and reputation, he must go there; he finds happiness in there (Kutadgu Bilig, 3462. couplet) It is possible to further examples of the above-mentioned. Because many mirrors for princes start talking about justice. However, as a third important dimension here with justice, it will be appropriate to look at the Verge of Justice approach. 
If we start with the metaphor of the subject circle, the verge is more than the circle because it has both the envelope of the circle and the inside. The Verge of justice is an approach rather than a concept, and it is also a system. It is claimed that the origin of the understanding of the Verge of Justice goes back as far as to Sumerians. With much debate in this regard, it is undoubtedly the fact that this frame system is involved in the same time as the mirror for prince written in many places from Iran to the Arabic geography, then to the Ottoman capital.

Verge of Justice is a management system. It is a political sovereignty. Verge of justice is the management of economic, social and political things. Due to its many different applications, the chain of circles is a cyclical chain of management in which the numbers are changing but the central concept of justice and key concepts has not changed. It is possible to catch important codes of the present state system through this system when considering the basic elements of the Verge of Justice as a structural-functional characteristic of the agrarian society or as the management information of traditional agrarian societies (YImaz,2012: 17-29) . It is possible to follow this system of Justice- State-Shariat-Country-ArmyProperty-People-Justice with the help of figure 1. According to that, the justice circle operates as follows.

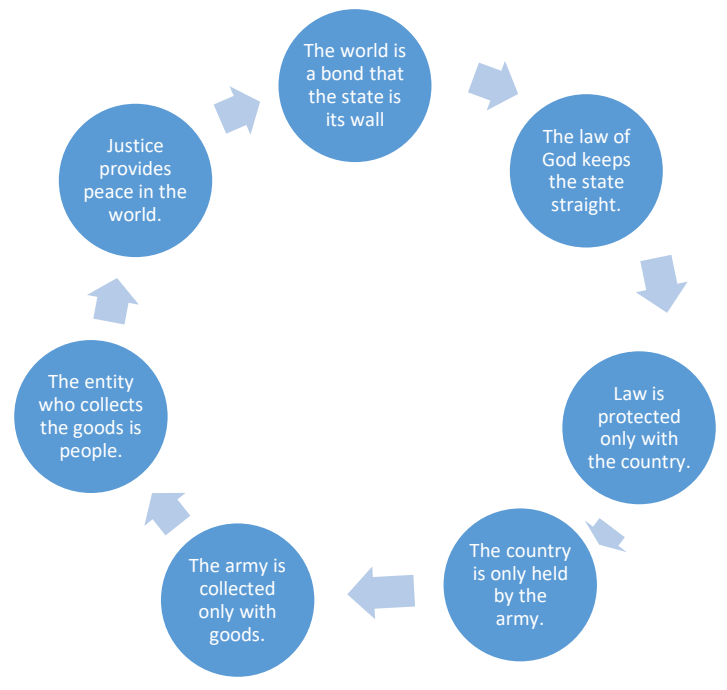

Figure 1: Daire-I Adalet (Circle of Justice or Power)

As understood from the circular system in the form of a verge above, the state is bound to the law, law to country, the country to army, the army to the money, money to the public and public to justice. Here justice has a broader notion than law. It is clear that the concepts such as country, people and power are the basic elements of the state and that it requires a current system like the military financial resource system. All of this system is endowed with the essence of adultery by many authors, as well as by the writer. The whole of this system is based on the essence of justice, which is seen by many authors of mirrors for princes as important.

\section{Leader Typology of Mirrors for Princes}

Adept Father: When the mirrors for princes are examined, it appears that lots of elements can be counted as the ideal leader's characteristics, most of which are abstract. However, some of them come to the fore. First, it can be said that it is a kind of loving father figure. In fact, the perception of politics, or more precisely, the perception of power as male sovereign has existed since ancient Greeks, even from Russia and even Mesopotamian civilizations. For example, in history, it is known that at the head of the cities there are the administrators called Babaghug in the sense of the father of the city. (Kıldıroğlu,2016: 114) In Kutadgu Bilig, it is said "If the father is the ruler, the son is born, and he becomes the ruler like his father." (Kutadgu bilig, 1950 couplet) But this male sovereignty state is somewhat of a family concept and sociologically identical to his father, the father figure who protects and protects him, and is seen as having a direct word on it. In this case it would be insufficient to explain it only with patriarchy or masculinity. While the figure of the state is being examined, it is seen that the family metaphor is brought forward with the thought of cooperation and solidarity, and the state is portrayed 
as a large family. (Köylü,2016: 201) According to this understanding, in the Turkish States; often state is regarded as father, motherland as mother, and nation as children. (Duman,2016: 197)

Because of the abstract nature of the state concept, the father is more identified with the ruler as a symbol of power. The merciful and protective aspect of the rulers also makes him look like a father. (Çapraz,2016: 127) When we look at the subject through the mirrors for princes, it is understood that this compassionate guardian, but also the symbol of authority and power, continues to exist for the rulers of the father figure. Ibn al-Mukaffa, for example, approached the subject by saying, "If the Sultan sees you like a brother, you will see him as a father." (Mukaffa,2016:.61) In the Kabusname, it is said that "the wise man knows his master as his father, mother and sister." (Keykavus: 230) According to Sadi Shirazi, the monarchs are portrayed as the father of orphaned children, and it is expressed that the orphans should be shown more affection and compassion than their fathers and suffer with their troubles. (According to Sadi Shirazi p.83) A similar approach is also seen in Tusi. So that the love of the ruler against the people is a father's love, the love of the people against him is a child's love, and if the people love each other, it should be brother's love. (Tusi,2016: .257) Türk: 115) This father-child relationship is of course not one-sided. So, Kınalızade takes the analogy a step further and says that the love of the people to their ruler is superior to that of the love of the father, but that the love of the ruler to the people is less than the love of the father to his child. (Türk,2012: 168)

A Religious Person: Being called as a sultan, a vizier, a sultan or a gentleman; a leader is a human being in the end. But he is a religious figure. Because the law required to keep society together and to govern the state, and the individual virtues also have a religious origin. The emperor has an important power of being the shadow of God that reflects on the world and has significant responsibility as required by the principle of balance. However, at the same time, he is a human and a subject of God. The first and the most important condition of being a good emperor is being a good religious and Muslim person. It is possible to monitor this situation from mirrors for princes.

The mirrors for princes refer not only to the rulers, but also to the religiousness of other important state officials. For example, the person in charge of state affairs must be knowledgeable, dignified, and of course must be true and religious. (Türk,2012: 186.) According to Kutadgu Bilig, Hajibs who helped in the service of the ruler must be a person who is pious and religious (Kutadgu Bilig, 2462. couplet) According to Ghazali, it is emphasized that a vizier is a religious person, a person who is confident in his / her right, moral and acting in a prudent manner in public affairs. Also, if the president is not smart and devout, he will be dismissed from his office soon after. (Gazali,130-138.) According to Maverdi, the head of state should know and take care of the supremacy of the science. Because it is what will make religious values alive. (Maverdi,2013:137) Ib-ni Mukaffa states that managers should not be able to behave in a way that religious people would not like as a means of love of service, and that virtue must be seen in religious people, and courage in towns, villages and tribes. (Mukaffa,2016:.55-66) According to Sadi Shirazi, only religiosity is important and the ruler must always keep the scholars and leaders of the religion as honorable. (Şirazi,2016: 80)

As you can see, religiosity is very important for a ruler. In such a structure it is almost impossible to expect the leader to have at least a position against religion, even if he is not a very religious person. Here, however, we must pay attention to an emphasis on religiousness, which is justice. As stated in Nizamül Mülk's politics and in some other important works, the expression "country may stay strong with kufr (unbelievers), but with injustice it will not." has become a common saying. (Koçi Bey, Gazali, Nizamul Mülk Siyasetname p.)

Roaring Lion: while people's relationship with nature enables them to find ways to struggle against its challenges, it also results in respect and taking it as example. In this sense, many animals in the nature have been symbolized with certain characteristics, and from this point of view, the way of analogy has been opened. For example, elephant is associated with greatness; fox is associated with canniness; snake is associated with sneakiness; and, rabbit is associated with cowardice. Similarly, lion is seen as the symbol of power, courage, authority, and potency. In Turkish classics, animals such as lion, tiger, and hawk are commonly used in the analogies about leadership. This analogy also reflects as a symbol of nobility. For example, Salur Kazan talks about his ancestry as saying that he has a root in Akkaya's tiger and Aksaz's lion. (Safran,2016:.32)

Lion is a king that has strong physical qualities and a powerful roaring sound that can be heard and felt from kilometres away. It is seen that this characteristic of lion is frequently used in metaphorical ways in terms of administration, and it is accepted and respected by the society. This is the reason why especially among Turkish people many famous leaders 
have lion (aslan ${ }^{1}$ ) as their names or surnames. Names such as Aslan Bey, Sultan Kılıçarslan, Arslan Taman Kağan, Arslan Yabgu, and Sultan Alparslan can be shown as examples of this.

The importance socially given to the lion is also observed in mirrors for princes. Historically, one of the most important duties of rulers is that they are also commanders; in this sense, the characterization of lion is an emphasis on the ruler's quality of being commander. It is not surprising when it is thought that some of the qualities a commander should have are courage, bravery, power, and fearlessness. In addition to this, powerful oratory is still seen one of the most prominent qualities of a leader. A commander who roars like a lion and spreads fear among the enemy but also motivates his herd is surely considered as having leadership qualities. One of the texts in which the most important analogies about lion takes place is Kutadgu Bilig. Yusuf Has Hacib initially interrelates language and lion. Language is a lion; and if the owner of it is not careful, it will get the owner into trouble. (Couplet 164) According to another couplet, it is written that to rule over the world and to overcome wild ass, one should be lion. Beys are similar to lions, and if a lion leads dogs, dogs will act like lions; if a dog leads lions, lions will act like dogs. (Kutadgu Bilig, Couplets 284,764, 2047, 2048) According to İbnül Tıktaka, a good ruler should be more aggressive than a lion. (Tiktaka,2016: 12)

Lion does not only represent positive characteristics. According to Gazali, a ruler who cannot placate has nature of an animal just like a lion disguised as a human. (Gazali,2016:.62) According to Ibni Mukavva, a person who is close to the ruler is like one who rides a lion. The one who looks at him feels scared but it is more frightening for the lion. (Mukaffa,2016: 58) according to Essealibi, a predatory lion is better than a cruel ruler (Türk,2012: 118).

Well, is not there any solution if a ruler who is as courageous and powerful as a lion is cruel or does not know how to act? According to Sadi Şirazi, although cat seems weak and feeble, it can beat lion by scratching lion's eyes out with its nails. Again, if ants reach a consensus, they can make the lion regret the day it was born. (Şirazi,2016: 119,122) Attar, on the other hand, states that a ruler should have necessary qualifications by making analogy that when a lion is without its teeth and nails, it is treated as cripple by foxes. (Attar,2013: 83) Finally, as one of the authors who care about lions most, Yusuf Has Hacip indicates that a person who knows how to manipulate and to play tricks can even deal with a lion. (Kutadgu Bilig, couplet 2327) To summarize, it is important for a ruler to be a lion; but it is more important for him to stay as lion.

Fair Shepherd: The metaphor of shepherd is also closely related to nature and culture. As it is known, a great deal of people in this geography earn their lives through stockbreeding. In fact, Turkish people are known as migrant settlers since they live in a mobilized way with their herds. Shepherd has interesting characteristics. He has a herd that has different types of animals having different qualities such as sheep, goats, females, males, babies, and grown-ups. While a shepherd is pasturing his herd, he does not discriminate; he aims to feed and protect them all. What is beneficial for the herd in the production and protection process is also beneficial for the shepherd.

The Arabic version of the word shepherd is râinâ. It is considered that companions of Prophet Muhammad addressed to the prophet as Ra'inâ meaning protect us, but did not refer to the meaning shepherd in this context. (Kur'an,2011:22) Again in Koran, in Surah of Bakara, the situation of the prophet against the ones who do not believe is liken to a shepherd who calls out and a herd that does not hear anything. (Surah Of Bakara, 171. Verse) Similarly, in the Old Testament, the statement "God who shepherds me through my life" is mentioned. (Genesis 48)

In such a social reality environment, it is seen that the metaphor of shepherd is one of the most determinant qualifications. By indicating that like all herds need a shepherd, society also needs a governor, Maverdi states that although people are not happy with this situation, it is better than living without a governor. (Maverdi,2013: 60) EbûMansur es-Seâlibi, on the other hand, indicates that just like a herd would be destroyed without a shepherd, people will also destroy each other without a ruler (EbûMansur es-Seâlibi, Âdabu'l-Mulûk, p. 33 as qtd.: (Türk,2012: 23)

Also, Katudgu Bilig describes the society as a herd and the bey as a shepherd, but he states that shepherd should be merciful while treating the herd. (Kutadgu Bilig, 1412. Couplet) Based on hadith, IbnTeymiye uses the statement "you are all shepherds and you are responsible for the ones you shepherding." (Türk,2012: 153) By referring to the Prophet, Gazali writes that each shepherd will be questioned about where he pastured the herd and how he treated the herd, and each ruler will be questioned about how he treated his people. (Gazali,2016: 120) According to Sadi Şirazi, a leader should not

1 "Pipeline creates tribal dissent," Indian Country Today, 27 September 2010. 
be only fair but he should also be guardian. As a shepherd would keep the wolf out of his herd, ruler should also keep bad people out of his society. (Şirazi,2016: 89)

Well, does the ruler exist for the society or does the society exist for the ruler? IbnTıktaka summarizes the topic by stating that the ones whose shepherd is wolf torture themselves. (Tıktaka,2016: 42) Sadi Şirazi, on the other hand, states it more clearly when he says herd is not there for the shepherd but the shepherd is there to serve the herd. (Türk,2012: 143) However, this situation does not fill the gap between leader's effect on the society and the society's effect on leader.

When all these illustrations are considered, shepherd has a wise, protector, and self-sacrificing personality. But the shepherd is also the irreplaceable one for the herd and he has the right to decide about the herd. Also, if the herd is shepherd's own property, his rights will be more. In this metaphorical narration, the meaning of being for the shepherd is that shepherd's livelihood and even life depends on the herd but also the herd's life depends on the shepherd because while the shepherd can sacrifice some to feed himself or to please his guests, the herd cannot take a risk of living without a shepherd.

\section{Conclusion}

There are some historical facts that shape societies, political administrative institutions embedded in them, concepts, and titles. Each society undergoes a change in terms of its main components, and depending on its knowledge about other societies, it obtains some new qualities or loses some old qualities, institutions, and habits. Especially the development of mass communication and transportation seems to approximate societies and values. On the other hand, there are also historical administrative codes that societies bring from their pasts. It is seen that today, many habits experienced in the society, the facts known by people, and the rituals repeated by new generations are based on a historical root because societies have memory; and the experience, habits, truths, and faults continue to exist by being transferred from one generation to the other. When considered from this point of view, understanding the past means understanding the present events or situations better. Within the context of this study, mirrors for princes can have an active and facilitative function in understanding political and administrative facts occurring in today's Middle East, and the perception of leadership that gains importance in this context.

Although the roots of mirrors for princes date back to much earlier times, this study focuses on fundamental texts found in the geography of Middle East after Islam. As a result of the analysis, it is possible to make some observations. Addressed with different names, mirrors for princes have been basic political and administrative texts of this geography. It is observed that Eastern mirrors for princes are structured on three fundamental factors; these are religion, balance, and justice.

From the perspective of leader typology, it is seen that the descripted or idealised leader is a benevolent father for his children, a fair shepherd for his herd, and a religious person who roars against his enemy. When we take a look at it in today's perception, leaders are people who have weaknesses in front of the society and God although they have many strong personality traits. This person is religious, and develops an identity within a moral doctrine.

The symbolization of the leader through the use of lion metaphor is observed with the qualities of power, authority, and oratory. As the threat or the perception of threat in the society increases, a lionhearted leader who roars is appreciated more. Although people themselves are sometimes scared of the roaring of their own leader, they have an absolute faith that this roar will protect them in dark forests.

The father figure is generally benevolent. The real expectation from him is to act with compassion. However, as indicated by a common statement, the father both loves and beats. Father's approach to his children defines his worldview, and a good part of it is based on unwritten social rules called mores. Mores do not only have a negative meaning as it is expected, on the contrary, it is a way of having government and laws in a migrant settler society.

The perception of a fair shepherd is not interpreted in a negative concept by the people who are called herd. To give examples from the recent past, it is understood from the statements of politicians who says that this duty cannot be fulfilled by the people who cannot shepherd two geese or three sheep. It is also an indicator that people are not disturbed by the nickname, shepherd, of a leader who is one of the most important political figures in recent past of Turkey. Like a shepherd who does not sacrifice his herd, leaders also protect their teams although they make frequent mistakes. This is about 
balance. The distortion of this justice-centred balance is one of the most serious dangers for both the leader and the society. The worldview of this geography's people, which is based on emotions rather than logic, also reflects in mirrors for princes; this situation shows itself in the fact that the determinant is moral rather than material, and the subject rather than the system. It is observed in mirrors for princes that there is a dominant understanding based on happiness rather than wealth and prosperity, on justice rather than order, on leader rather than system, on courage rather than weapon, and on governor rather than government.

\section{References}

[1] Black, A. (2008) The West And Islam, Oxford University Press Inc., New York.

[2] Black, A. (2011) A World History Of Ancient Political Thought Edinburgh University Press, Edinburg

[3] Çapraz, H. (2016) "Türk Devletlerinde Hükümdarlı̆ı̆ı Kaynağı ve Özellikleri”, Tdyg, Mü Yay.,

[4] Çubukçu, I. (?) İslam Düşünürleri , AÜ Illahiyat Fak. Yay., Ankara

[5] Duman S. (2016) "İslam Öncesi Türk Devletlerinde Aristokrat Cumhuriyet" Tdyg, Mü Yay.,

[6] Ebü'n-Necib Şeyzeri (2013) Nehcü’s Sülük Fi Siyaseti’l Mülük, Haz: Ensar Köse, Büyüyen Ay Yay, İstanbul.

[7] Eski Ahit

[8] Feriüddin Attar (2013) Pendname (Haz: Yusuf Çetindağ) , Etkileşim Yay., İstanbul

[9] Fodor, P. (1999) 15-17. "Hükümdar Aynalarında Devlet Ve Toplum" Çev: Erdal Çoban), Ege Üniversitesi Tarih Incelemeleri Dergisi,281-302.

[10] Hopaç, M (2016) "Farabi'de Devlet Anlayışı" ,Tdyg, Mü Yay.,

[11] İbnü't Tıktaka (2016) El-Fahri Haz: Ramazan Şeşen, Bilge Kültür Sanat, İstanbul

[12] İbnül Mukaffa (2016) İslam Siyaset Üslubu, (Çev: Vecdi Akyüz) Dergah Yay, İstanbul

[13] İmam Gazali (2016) Nasihatü’l Mülük, (Çev: Osman Şekerci) Büyüyen Ay Yay., ,İstanbul.

[14] İnalcık H. (1965) "Adaletnameler", Türk Tarih Belgeler Dergisi,1965 Cilt lı (Sayı 3-4 Ten Ayrı Basım)

[15] Keykavus (?) Kabusname 1 Cilt , Tercüman Yayınları, İstanbul

[16] Kıldırolu M. (2016) "İslam Coğrafyacılarına Göre Hazar Hakanlığı Devlet Yönetim Birimleri ve Sonraki devletler Üzerinde Etkisi", Tdyg, Mü Yay.

[17] Köylü M. (2016) “İslamiyet Öncesi Türk Devlet Yapısı ve Törenin Etkisi”, Tdyg, Mü Yay.

[18] Kur’an-I Kerim Meali (2011) Diyanet İşleri Başkanlığı Yayınları

[19] Levend, S (1962) "Siyasetnameler", Türk Dili Araşıımaları Yıllığı Belleten, Ttk Basımevi.

[20] Maverdi, (2013) Yönetimin Esasları, Illke Yayınları, İstanbul

[21] Nasiruddin Tusi (2016) Ahlak-I Nasıri, Litera Yayıncllık, İstanbul.

[22] Nizam'ül-Mülk, (1999) Siyasetname Haz: Mehmet Altay Köymen ), TTK Yay, Ankara

[23] Sadi Şirazi (2016) Hükümdarlara Öğütler) ( Haz. Nimet Yıldırım), Bilge Kültür Sanat, İstanbul

[24] Safran, M. (2016) “Türk Kültüründe Liderlik", Tdyg, Mü Yay.,

[25] Taşağıl, A. (2003) Göktürkler 1, TTK Yayınları, Ankara

[26] Türk, B. (2012) Çoban Ve Kral, İletişim Yayınları, İstanbul.

[27] Uğur, A. (1992) Osmanlı Siyasetnameleri, Erciyes Üniversitesi Yayınları, Kayseri

[28] Yılmaz Uçar, A. (2012) "Osmanlı Siyaset-Yönetim Düşün Geleneği: Daire-I Adalet' in Yönetimi" Memleket Siyaset Yönetim Dergisi Cilt 7 Sayı 17 S. 5..) Ankara

[29] Yusuf Has Hacip, Kutadgu Bilig,( Haz: Muhammed Doruk,) Erciyes Üniversitesi, Edebiyat Fak. Türk Dili Ve Edb Bölümü.

[30] Www.Eba.Gov.Tr (July,2017) 